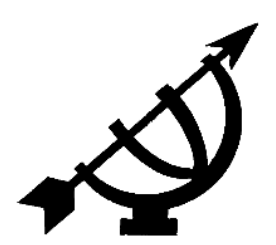

\title{
Besit waardes rigtinggewend-normatiewe waarde? 'n Beoordeling van die Noordwes-Universiteit se waardeprojek
}

\author{
B.J. van der Walt \\ Skool vir Filosofie \\ Potchefstroomkampus \\ Noordwes-Universiteit \\ POTCHEFSTROOM \\ E-pos: hannah@intekom.co.za
}

\begin{abstract}
Do values contain directional-normative value? A review of the value project of the North-West University
\end{abstract}

As indicated in the title, the aim of this article is to determine the value (if any) of values, especially as expressed by a valuedriven institution. To avoid abstract reflection, the article (cf. the subtitle) focuses on a specific institution, viz. a university. To concretesise the investigation even more, the North-West University (which came into existence in 2004) is taken as a case study. The investigation develops as follows: by way of introduction, attention is first given to the popularity of present value thinking, followed by the problem statement: Are such values really capable of indicating a normative direction? Secondly, the development of a university with a normative foundation (the erstwhile Potchefstroom University for Christian Higher Education) towards a value-driven one (the new North-West University) is briefly described. In the third place a brief description of the NWU as a value-driven institution is given. Fourthly, attention is given to some practical problems which surfaced during the implementation of the value project. Fifthly, six theoretical-philosophical problems regarding the NWU's value system are discussed. The next main point consists of a brief description from a reformational perspective (of structure, direction and relevance) of what an academic institution ought to be. Apart from expressing doubt about the real value of values to give a solid foundation and clear direction to a university, the preliminary conclusion also suggests further 
philosophical reflection on the real nature, status and authority of values.

\section{Opsomming}

\section{Besit waardes rigtinggewend-normatiewe waarde? 'n Beoordeling van die Noordwes-Universiteit se waardeprojek}

Soos die titel aandui, wil hierdie artikel die waarde (indien enige) van waardes ondersoek, veral soos uitgedruk in 'n waardegedrewe instelling. Om nie abstrak te wees nie, fokus die artikel op 'n spesifieke instelling, naamlik 'n universiteit ( $\mathrm{vgl}$. die subtitel). Om die ondersoek meer konkreet te maak, word die Noordwes-Universiteit (wat in 2004 tot stand gekom het) as 'n gevallestudie gebruik. Die ondersoek verloop soos volg: ter inleiding word eers op die hedendaagse populariteit van waardedenke gewys, gevolg deur die probleemstelling of waardes werklik daartoe in staat is om normatiewe rigting aan te dui. Tweedens word die oorskakeling van 'n universiteit met 'n beginselgrondslag (die eertydse Potchefstroomse Universiteit vir Christelike Hoër Onderwys) na 'n waardegedrewe universiteit (die nuwe Noordwes-Universiteit) geskets. In die derde plek word die nuwe waardegedrewe NWU van nader bekyk. Vierdens volg 'n besinning oor veral die praktiese probleme rondom die implementering van hierdie waardeprojek. Vyfdens word ses filosofies-teoretiese probleme in verband met die waardestelsel na vore gebring. Die volgende hoofafdeling bestaan uit 'n kort beskrywing vanuit 'n reformatoriese perspektief (van struktuur, rigting en relevansie), van wat 'n akademiese instelling behoort in te hou. Daarna volg 'n voorlopige gevolgtrekking waarin twyfel uitgespreek word oor die werklike waarde van waardes om 'n vaste basis en duidelike rigting aan 'n universiteit of ander samelewingsverband te kan gee. Dit is egter 'n voorlopige gevolgtrekking, aangesien dit aan die einde van die ondersoek ook duidelik is dat verdere filosofiese besinning oor die aard, status en gesag van waardes noodsaaklik is.

\section{Inleiding: aktualiteit, probleem, standpunt en opset}

Enkele opmerkings ter inleiding is noodsaaklik om iets van die aktualiteit van die tema te verstaan, die probleem wat dit inhou te identifiseer, asook die opset van die ondersoek te verduidelik.

\subsection{Aktualiteit}

Gedurende die modernisme of rasionalisme $( \pm 1700-1900)$ is feite en waardes meestal geskei. Ware wetenskap moes slegs op die konkrete (meet, weeg, tel en sigbare) feite konsentreer. Om van waardes te praat of enige waardeoordele of -voorskrifte te maak, is 
as onwetenskaplik beskou. Onder die invloed van die irrasionalisme (ná 1900), is egter geleidelik besef dat hierdie soort neutraliteit skyn was. Geen mens kan van waardes (in 'n normatiewe sin) ontkom of die vraag ontwyk hoe hy/sy behoort te lewe nie. Die woord moord gee byvoorbeeld nie slegs 'n feit weer nie, maar bevat reeds die beoordeling dat dit 'n abnormale sterfte was.

Tans word daar feitlik op alle lewensterreine gereeld gepraat van "waardeverlies" en selfs 'n "waardekrisis". 'n Voorbeeld daarvan, wat die Suid-Afrikaanse samelewing betref, is dié van Swartz (2006). Dieselfde geld op die gebied van die onderwys (vgl. De Klerk \& Rens, 2003) - ook internasionaal (vgl. Aspin \& Chapman, 2007).

Daar word verder baie algemeen van die veronderstelling uitgegaan dat nuwe waardes as 'n soort panasee kan dien om die verval op feitlik enige lewensterrein te stuit. Daarenteen praat diegene wat nie deur hierdie modegier beïndruk is nie, eerder van 'n "waardekultus" of 'n "gedweep met waardes". Wat behoort 'n mens se standpunt in hierdie debat te wees? Dit is 'n belangrike vraag, want die irrasionalisme se onsekerheid oor vaste beginsels en norme, een van die redes vir die toevlug tot waardes, is met die koms van die postmodernisme verskerp. Verder word hedendaagse samelewings gekenmerk deur 'n multireligieuse en -kulturele karakter. Dit word ook gereflekteer in instellings soos universiteite. Wát sulke samelewings kan saambind, word al hoe belangriker. Sou gedeelde of gemeenskaplike waardes nie moontlik 'n oplossing kon bied nie?

\subsection{Die probleem}

Die hedendaagse populariteit van waardes verraai onsekerheid en is basies 'n vraag na rigting, na wat gedoen behoort te word en na normatiwiteit. Die vraag bly egter of waardes in staat is om nuwe koers aan te dui. Dit hang van die aard en status (gesag) van waardes af. Om dit te bepaal, moet waardes filosofies geanaliseer word.

Om nie in abstraksie te verval nie, word hierdie bydrae op 'n konkrete voorbeeld toegespits. Uit die baie gevalle waar waardebewustheid as remedie aanbeveel word, word slegs die universiteitswese gekies. Om dit verder te konkretiseer, val die fokus op die Noordwes-Universiteit (NWU) - die naam wat die Potchefstroomse Universiteit vir Christelike Hoër Onderderwys (PU vir $\mathrm{CHO}$ ) sedert die begin van 2004 dra. Laasgenoemde (tans die Potchefstroomkampus) het van 'n beginselgedrewe na 'n waardegedrewe universiteit ontwikkel. Wat hou dit presies in? 


\subsection{Standpunt}

Om wat volg beter te verstaan, is dit nodig dat die outeur vooraf duidelik standpunt inneem. Sy vertrekpunt is geïnspireer deur 'n reformatoriese-filosofiese tradisie (vgl. 6 hieronder). Dit hou onder andere in dat geen instelling neutraal kan wees of kan funksioneer nie, maar ' $n$ sekere koers of rigting, wat ten diepste religieus bepaald is, moet voorstaan. Christelike, Moslem, Hindoe en sekulêre universiteite is dus moontlik, selfs normaal. Ook 'n sekulêre oriëntasie behels ten diepste 'n geloofstandpunt. Indien 'n mens dus aan waardes normatiewe krag toeken, is elke akademiese instelling eintlik waardegedrewe en die NWU se nuwe waardes niks besonders nie. Volgens die skrywer moet waardes egter vaster en dieper in God se skeppingsorde en sentrale liefdesgebod begrond word om van enige waarde te kan wees. Verder kan die vraag gestel word of die NWUwaardes, ook al word hulle Christelik ingekleur, die Potchefstroomkampus teen uiteindelike sekularisering kan beskerm.

\subsection{Die opset}

Hierdie ondersoek is soos volg opgebou: Eerstens word die verloop vanaf ' $n$ universiteit met 'n beginselgrondslag (die eertydse PU vir $\mathrm{CHO}$ ) na 'n waardegedrewe universiteit (die nuwe NWU) kortliks geskets. Tweedens word die nuwe waardegedrewe NWU van nader beskou. In die derde plek volg 'n besinning oor veral praktiese probleme rondom hierdie waardeprojek soos wat dit by verskillende geleenthede sedert die implementering daarvan na vore gekom het. In die vierde plek word, ná hierdie meer voor die hand liggende vrae, ses indringender teoreties-filosofiese probleme met die waardestelsel na vore gebring. Vyfdens word vanuit drie kernbegrippe (struktuur, rigting en relevansie) 'n eie visie as teenvoeter vir 'n waardegedrewe universiteit geskets. Ten slotte word 'n voorlopige gevolgtrekking gemaak waarin onder andere genoem word dat die artikel verdere, dieper Christelik-filosofiese besinning oor die presiese aard, status en gesag van waardes oproep.

\section{Die ontwikkeling van 'n beginseluniversiteit na 'n waardeuniversiteit}

Tot die einde van 2003 het die Potchefstroomse Universiteit die van "vir Christelike Hoër Onderwys" (CHO) gedra (kortliks: die Puk). Die van is statutêr as die Christelik-historiese grondslag van die Puk beskryf. Die amptelike leuse (aan Ps. 36:10b, OAV ontleen) was "in $U$ lig", met 'n kandelaar as embleem, wat daarop gedui het dat ook die wetenskap in die lig van God se openbaring beoefen behoort te 
word. Vanaf die begin van 2004 word die Puk deel van die groter NWU, wat ook die Universiteit van die Noordweste (op Mafikeng) insluit, en daarmee het sy Christelike grondslag (sy "van"), asook die leuse en embleem verval. Dit is belangrik om iets meer in verband met hierdie belangrike ontwikkeling te verduidelik.

\subsection{Die PU vir CHO}

Die ietwat vae Christelik-historiese karakter, die van en leuse van die Puk is in die loop van sy bestaan geïnterpreteer en duideliker inhoud gegee. Die ideaal was (vgl. Du Plessis aangehaal in Reinecke, 1998:9) dat die "CHO" op 'n integrale, reformatories-Christelike lewensvisie as grondslag sou dui. Daarvolgens word die soewereiniteit van God en sy verordeninge en die koningskap van Christus oor elke lewensterrein, die akademie ingesluit, as vertrekpunt sentraal gestel. Enkele historiese flitse is die volgende:

- By die honderdjarige herdenking van die Puk (1969) verskyn twee bundels wat hierdie ideaal verwoord. Tydens die fees verskyn Die atoomeeu - 'in U lig' (cf. Duvenage, 1969) en ná die geleentheid Besinning en uitsig (vgl. Duvenage, 1971).

- Onder leiding van prof. T. van der Walt as rektor (1977-1987), word nogeens gepoog om "vlees en bloed" aan die Puk se karakter te gee deur 'n akademiese belydenis of credo op te stel. Ongelukkig is hierdie dokument egter nooit ná prof. Van der Walt se uittrede gefinaliseer of amptelik aanvaar nie. Die byna finale teks (deur die betrokke komitee vir die Christelike karakter van die PU vir $\mathrm{CHO}$ ) is later in Afrikaans (vgl. Van der Walt, 1992: 541-545) en Engels (vgl. Van der Walt, 1994:592-595) gepubliseer.

- Vir die 125-jarige herdenking van die Puk (1994) is daar aan 'n gedenkbundel met talle artikels gewerk wat eers vier jaar later (in 1998) as 'n supplement van die tydskrif Koers onder die titel Verkennings in oorgang (vgl. Reinecke, 1998) verskyn het. In sy inleidende samevattende oorsig skryf Du Plessis (Reinecke, 1998:5) onder andere dat die grondslag van die Universiteit "handel oor die religieuse oriëntasie, die geloofsbasis, die gepaardgaande norme en riglyne om aan ' $n$ universiteit in diens van God en tot seën vir die naaste te doseer, na te vors, te bestuur, te bedryf". So 'n universiteit impliseer nie 'n kerklike instelling nie, maar "'n werkswinkel van die wetenskappe waar gewerk word vanuit Reformatoriese beginsels" (Reinecke, 1998:7). 
Die titel van hierdie bundel suggereer alreeds 'n oorgang of die begin van 'n transformasieproses. Daar word egter nog gesê dat die Christelike karakter nie as 'n struikelblok in so 'n proses beskou mag word nie. Die transformasie sal "op die basis van die Christelike grondslag aangepak moet word" (Reinecke, 1998:11). Dit sal beteken dat die Puk nie in die toekoms 'n voorstander van 'n neutrale wetenskapsbeoefening word of in postmoderne relativisme verval nie (Reinecke, 1998:12, 13). Hierdie was egter die laaste versamelwerk oor die Puk waarin die Christelike karakter nog as vanselfsprekend aanvaar is.

\subsection{Die doodsnikke van 'n ou bedeling}

Drie fases kan in hierdie periode onderskei word.

\subsubsection{Invloed van die Vrije Universiteit}

Die ontwikkeling by die Vrije Universiteit (VU) in Amsterdam het ongelukkig - tot 'n groot mate ook die ontwikkelings by die Puk die laaste tien jaar voor 2004 bepaal. Nadat die vrede tussen die Puk en die VU herstel is (vgl. Schutte, 2005:455 e.v. vir die voorafgaande geskiedenis) het die Puk-bestuur al meer na sy Europese "moeder" vir oplossings van sy probleme opgekyk.

Die VU het sedert die sewentigerjare egter geleidelik 'n sekulêre instelling geword. Sy grondslag is vroeër reeds verander tot 'n vae doelstelling: "De Universiteit stelt zich ten doel, overeenkomstig de grondslag van de Vereniging, al haar arbeid in gehoorsaamheid aan het Evangelie van Jezus Christus te richten op het dienen van God en zijn wêreld" (Haan \& Van Harskamp, 1991:97). Hoewel ook teëstand, was daar aanvanklik heelwat instemming met hierdie nuutgeformuleerde doelstelling (vgl. Verhoogt, 1981).

In die bundel van Haan en Van Harskamp (1991) word egter 'n uitvoerige debat gevoer (vgl. die subtitel) of die besondere (Christelike) aard van die VU nie liewer afgeskaf moet word, sodat dit 'n gewone universiteit kan word nie (vgl. ook die anonieme VU-publikasie van 1991, De Vrije Universiteit: gewoon bijzonder). Ook die Vereniging voor Wetenschappelijk Onderwijs op Gereformeerde Grondslag (vgl. Roelink, 1979), wat die VU tot stand gebring het, kon blykbaar nie hierdie ontwikkeling stuit nie.

Van die behoudende personeel reageer daaroor soos volg (vgl. Haan \& Van Harskamp, 1991:25): 
Die begrip Christelik word in so 'n algemene sin gebruik dat dit feitlik niks meer sê nie. Bowendien is die 'Christelike' slegs nog van marginale betekenis vir die beoefening van die wetenskap.

lemand anders skryf:

Zolang de VU te 'gewoon' is om 'bijzonder' te zijn en nog te 'bijzonder' om 'gewoon' te zijn, en, zolang het VU-bestuur, het 'gewone' nauwelijks 'bijzonder' benadrukt, zet zij haar 'meerwaarde' succesvol in voor haar ondergang als 'gewoon bijzonder' universiteit. Ik betreur de tendentie. Bovendien vraag ik mij af of er voldoende toekomst is voor de VU als 'gewone' universiteit. (Haan \& Van Harskamp, 1991:25.)

Nog 'n ander stel kategories dat die VU sy bestaansreg verloor as dit sy doelstelling (besondere karakter) sou loslaat (Haan \& Van Harskamp, 1991:72).

Die waarheid van hierdie stelling blyk duidelik uit die nuwe visie van die VU op die verhouding tussen geloof en wetenskap. Die nuwe visie word veral duidelik indien 'n mens dit vergelyk met dit wat reformatoriese denkers soos Van Riessen (1982:119 e.v.) 'n dekade tevore oor die onderwerp geskryf het. In plaas van 'n spanning of skeiding tussen geloof en wetenskap, is daar tóé nog van die gedagte van 'n gelowige wetenskap uitgegaan - elke soort wetenskap (van Christene en nie-Christene) word deur geloofsveronderstellings gelei.

Volgens die nuwe ontwikkelingsplan van die VU-raad vorm geloof en wetenskap nie meer 'n integrale eenheid, 'n gelowige wetenskap nie, maar is dit gelykwaardige maniere van ken, wat langs mekaar staan (vgl. Haan \& Van Harskamp, 1991:20). Op dieselfde bladsy word vermeld dat dr. H.J. Brinkman (invloedryke voorsitter van die College van Bestuur) van mening is dat geloof en wetenskap twee maniere van ken is, wat nie tot mekaar herleibaar is nie en waarvan die een die ander nie mag oorheers nie.

Hierdie oeroue, valse dualisme tussen wete(nskap) en geloof blyk byvoorbeeld duidelik uit Brinkman (1992:8) se eie voordrag:

De outonomiteit van de ... wetenschap, die zo belangrijk is voor de kwaliteit van wetenschapsbeoefening ... kan een noodzakelijk en sterk komplement en tegenwicht vinden in een christelijk levensleer ... het gaat om tegelijk christelijk geloven en beoefening van de wetenschap. 
Let daarop dat die wetenskap nou outonoom is en dat dit ook kwaliteit waarborg. (Vir die hewige diskussie wat hierdie rede van Brinkman binne die VU-geledere uitgelok het, vgl. Haan \& Van Harskamp, 1993.)

Hierdie dualistiese denke loop dan ook uiteindelik daarop uit dat daar nie meer van "Christelike wetenskap" nie, maar slegs van "Wetenskap deur Christene" gepraat kan word (vgl. Haan \& Van Harskamp, 1991:106). Die VU gee nie meer Christelike onderwys nie, maar gewone, goeie, uitnemende onderwys en navorsing van hoë kwaliteit (Haan \& Van Harskamp, 1991:42). Soos uit die verskillende bydraes in Haan en Van Harskamp (1991) blyk, het op die ou einde slegs 'n paar sekulêre waardes van die VU se besondere (Christelike) karakter oorgebly. (Vgl. Tervoort, 2005; Van Deursen, 2008.)

\subsubsection{Die Puk loop 'n soortgelyke pad}

Die "gevry met die Vrije" het, soos alreeds genoem, ook tot 'n groot mate die Puk se toekomspad bepaal. Hoe ander Christelike universiteitskolleges met hulle Christelike karakter omgegaan het, is sover vasgestel kon word, nie oorweeg nie. Vergelyk die volgende dokumente oor Dordt College (1961; 1968; 1979; 1993; 1996), en Zylstra (2004). Vergelyk verder die ryk geskiedenis van Dordt College soos vervat in Vanden Bosch (1990), Haan (1992), en Hulst (2005), die geskiedenis van Calvin College deur Timmerman (1975) en van die Institute for Christian Studies in Toronto deur Vander Vennen (2008). Redeemer Universiteitskollege sou ook by die lysie gevoeg kon word. Brinkman (en sy ander Europese raadgewers) word egter vir 'n hele aantal jare die hoofadviseur vir 'n nuwe Puk.

Geloof en wetenskap word (soos in die Sentrum vir Geloof en Wetenskap van die nuwe Puk) twee afsonderlike sake wat op een of ander wyse geïntegreer moet word. Vanaf 1992 kry die Puk ook drie waardes (waarvan die eerste duidelik aan die VU ontleen is), naamlik uitnemendheid, respek en prinsipiële denke as verklaring van sy Christelik-historiese karakter. Soos Venter (1994:304, 312) tereg skryf, gaan dit egter nie gepaard met 'n verklarende dokument waarvolgens die waardes geïnterpreteer kon word nie. Publieke debat kon ook nie daaroor gevoer word nie. Belangrik is egter dat die Puk van toe af al (en nie eers vanaf 2002 onder bewind van 'n nuwe rektor nie) tot ' $n$ waardegedrewe instelling omskep is.

\subsection{Die verloop vanaf 2002 tot 2003}

Van Eeden (2006:510 e.v.) skets die verdere verloop soos volg: 
In 2002 beveel 'n paneel bestaande uit Britse en Europese rektore in hulle oudit van die Puk aan dat die 'CHO' verval om van die apartheidsbagasie ontslae te raak. Die nuwe rektor, dr. T. Eloff (vanaf Februarie 2002), was ten gunste van dié voorstel, aangesien hy van mening was dat die Puk se van (CHO) die Christelike saak (a.g.v. die historiese beleid van $\mathrm{CNO}$ ) meer kwaad as goed kon doen.

Volgens die outeur was dit egter 'n té eenvoudige kompromis waarmee die Christelike karakter van die Puk verder prysgegee is. Daar moes eerder iets daadwerklik aan sy apartheidsgeskiedenis gedoen word.

Die personeel en studente was egter nie almal ten gunste van so 'n besluit nie. Vraelyste is ingevul en talle vergaderings is gehou. Die werkswinkel op 25 Februarie 2002 was seker die belangrikste daarvan. Dit blyk dat daar nie by almal ewe veel duidelikheid was oor wat met die karakter, grondslag, van en leuse van die Puk bedoel word en hoe dit prakties verwesenlik moes word nie. Verdere besinning was noodsaaklik.

Intussen het iets anders gebeur wat hierdie beoogde herbesinning egter gefnuik het. Met Eloff se rektorwording was daar nog nie sprake van die samesmelting van die Puk met die Universiteit van die Noordweste (Mafikeng) nie. Toe die saak egter op die agenda ('n opdrag van die ANC-regering) kom, het die karakter van die Puk self opnuut in die gedrang gekom. Wat presies tydens die onderhandelings met die regering plaasgevind het, word nie deur Van Eeden (2006) vermeld nie. Sy noem dat die debat (tussen die Pukowerhede en die regering se onderwysdepartement) oor die naam vir die nuwe universiteit teen Augustus 2003 so 'n groot probleem in die samesmeltingsproses geword het dat Eloff verklaar het dat dit onmoontlik geword het om die "CHO" te behou (vgl. Van Eeden, 2006:512). Dit sou volgens Eloff egter nie beteken dat die Potchefstroomkampus sy Christelike waardes verloor nie. Die Christelike grondslag en naam is dus vanaf die begin van 2004 met waardes vervang.

\subsection{Was dit werklik nodig om die CHO prys te gee?}

Dit kom die outeur van hierdie artikel nie toe om te oordeel oor hierdie uiters belangrike stap in die geskiedenis van 'n inrigting wat 134 jaar bestaan het en waarvoor baie geslagte hulle talente, tyd en geld opgeoffer het nie. Oor wat presies tydens die onderhandelings 
tussen die Puk en die nuwe regering gebeur het, het die outeur ook nie die nodige inligting nie.

Wat wel duidelik is, is dat die verlies van die Puk se CHO-van nie grondwetlik nodig was nie. 'n Oud-Pukdosent en internasionaalerkende regsgeleerde, Van der Vyver (1999:670) stel dit duidelik dat die nuwe Grondwet van Suid-Afrika nie, soos byvoorbeeld dié van die VSA, 'n sekulêre konstitusie is nie (en gevolglik tot vyandigheid teenoor ander godsdienste kan lei nie) maar 'n religieus-neutrale grondwet is.

In 'n lesing wat Van der Vyver in 2000 spesifiek oor die toekoms van die Puk as Christelike universiteit gehou het, verwys hy, ter stawing van die feit dat die nuwe Suid-Afrikaanse regering neutraal teenoor alle godsdienste moet optree, na verskillende artikels in die Grondwet (vgl. Van der Vyver, 2000:10). Op die vrae of 'n universiteit in Suid-Afrika in beginsel en onder die nuwe grondwetlike bedeling eksplisiet Christelik mag wees, antwoord hy dus bevestigend (Van der Vyver, 2000:11).

Hy sluit soos volg af:

Die Grondwet erken nadruklik die reg van elkeen om onafhanklike onderwysinstellings op te rig (art. 29(3)) ... Hierdie bepaling geld eintlik nie vir die Puk nie, eerstens omdat die Puk 'n statutêre liggaam is, en tweedens omdat die Puk by die inwerkingstelling van die Grondwet ' $n$ reeds bestaande inrigting was. Die Puk kon hom dus vir handhawing van die status quo (sy Christelike karakter - BJvdW) op die beginsel van gevestigde regte beroep. (Van der Vyver, 2000:11.)

Dit is in die lig van hierdie feite dat die skrywer (vgl. 2.3) van mening is dat daar, ten spyte van die Puk se apartheidsverlede, te maklik boedel oorgegee is en dat daardeur iets baie kosbaars verlore gegaan het.

\section{3. 'n Waardegedrewe universiteit}

Vervolgens word gelet op die oorsprong van die waardedenke en daarna op die spesifieke waardes van die NWU.

\subsection{Die oorsprong van die waardes}

Twee sake is hier van belang, naamlik die oorsprong van die NWU se waardedenke en wat dit presies ingehou het. 
Van Eeden (2006:512) merk op dat die idee van 'n waardegedrewe universiteit nie van die Puk self gekom het nie, maar sy ontstaan gehad het by die ANC-Minister van Onderwys se pleidooi vir 'n nuwe waardestelsel binne die Suid-Afrikaanse onderwys (vgl. Van Eeden, 2006:514 se aanhaling van Minister Kader Asmal). Dit sou egter nie 'n vreemde gedagte wees nie, aangesien die Puk alreeds vanaf 1992 drie waardes aanvaar het.

Toe 'n missie en visie in 2003 vir die te stigte NWU opgestel is, is dus onder andere besluit om dit as waardegedrewe universiteit te definieer. In Junie 2003 skryf Eloff:

Through the negotiations of the past months we have established a broad framework for the NU (NWU). The strategy was to retain the fundamentals of the Puk or to create room for it in the NU (=NWU) ... among other things the Puk got ... room for living up to our Christian principles, and a Christian perspective on science. (Van Eeden, 2006:514, 622.)

Tereg voeg Van Eeden (2006:514) self daarby: "Net die tyd sou leer in welke mate beoog is om hierdie beginsels en perspektiewe in die nuwe tersiêre bedeling in stand te probeer hou."

\subsection{Die waardes van die NWU}

Die Raad van die NWU het die nuwe visie, waardes en missie aanvaar. Gedurende die hersiening van die Institusionele plan in 2007 is die eerste weergawe van die waardes hersien en herformuleer. Daarvolgens sluit die waardestelling die volgende tien waardes in:

Die Noordwes-Universiteit hang die waardes van menslike waardigheid, gelykheid, vryheid, integriteit, verdraagsaamheid, respek, toewyding aan uitnemendheid, wetenskaplike betrokkenheid, akademiese vryheid en geregtigheid aan.

Die eerste drie waardes is ontleen aan die Suid-Afrikaanse Grondwet se drie basiese beginsels. Respek en uitnemendheid is waarskynlik uit die bestaande drie Puk-waardes van 1992 oorgeneem.

Al hierdie waardes was blykbaar ' $n$ bietjie oorweldigend. Daarom vermeld die personeelblad van die NWU (2007:12) 'n ICARUSprojek, wat in Maart 2007 van stapel gestuur is. Uit die bogenoemde tien is vier doenwaardes gekies waarop die vraag ontstaan of alle waardes nie iets is wat gedoen/gerealiseer behoort te word nie. ICARUS is afgelei van die vier doenwaardes in Engels, naamlik integrity, commitment, accountability en respect plus die woord us (ons). 
Aan die personeel word verduidelik hoe hulle hierdie waardes behoort uit te leef.

Intussen is daar verder aan die waardestelsel gewerk, en in die NWU (2009:1) se alumnitydskrif word sommige van die waardes weer effens anders weergegee. In plaas van "toewyding tot uitnemendheid" word die woorde "verbondenheid tot" gebruik; en "wetenskaplike betrokkenheid" word met "vakkundige betrokkenheid" vervang. Verder word 'n elfde waarde, naamlik "deursigtigheid" aan die einde bygevoeg.

Blykbaar het selfs die topbestuur nie altyd presies geweet wat al hierdie waardes inhou en hoe hulle toegepas kan word nie. Dr. W.A. Landman lewer op 22 Junie 2009 lesings oor "The practical application of values" (sien 5.1). Opvallend daarin is die afwesigheid van wat in die wetenskapsfilosofie as "epistemic values" beskryf word, soos epistemic simplicity, epistemic fertility, epistemic consistency, epistemic integrity, ensovoorts (vgl. Strauss, 2009:298-317).

\section{4. 'n Besinning oor die waardes van die NWU}

Een van die belangrikste geleenthede wat die personeel gegun is om saam oor die NWU se waardes te besin, vind eers op 4 September 2008 plaas by 'n Puk-Forum met die tema "NoordwesUniversiteit: 'n waardegedrewe universiteit'.

\subsection{Reedsbestaande probleme}

Reeds in die bekendstellingspamflet vir hierdie byeenkoms word die volgende drie probleme geïdentifiseer:

- Is dit die regte waardes vir 'n universiteit, aangesien slegs twee van die elf akademies van aard is?

- Is elf waardes nie hopeloos te veel om te operasionaliseer nie? Moet dit nie tot drie of vier beperk word nie?

- Die meeste van hierdie waardes (behalwe twee) is nie leefwaardes nie, maar sogenaamde eindwaardes. Hulle stel die eindtoestand voor indien daar vryheid, geregtigheid, integriteit, ensovoorts sal heers. Is dit reg? Hoe kan mense met sulke eindwaardes gelei en geïnspireer word? Moet die vraag nie eerder wees watter soort gedrag instrumenteel kan wees vir die bereiking van die doelwitte wat die NWU se missie en visie voorstel nie? 
Nog baie meer vrae sou gestel kon word, soos byvoorbeeld wat presies doen-, leef- en eindwaardes is. Belangriker nog is wat die waardes presies behels.

\subsection{Nog meer vrae}

Tydens die debat het nog talle ander vrae na aanleiding van die lesings van dr. T. Eloff (2008) en prof. F. Venter (2008) na vore gekom. Hier volg eers 'n kort eie weergawe van die belangrikste punte van die twee inleidings.

\subsection{Verdediging van die NWU-waardes}

In sy historiese oorsig betoog Eloff dat dit polities en regstegnies onmoontlik was om die "CHO" van die Puk te behou. Waarom? Het Eloff en sy bestuur nie gekapituleer vir die ineentrek van struktuur en rigting nie? Klaarblyklik het hy ook nie die pleit gevoer vir die kollektiewe vryheid van die universiteit as instelling nie (vgl. 6). Die leemtes wat so ontstaan het, noem hy die filosofiese en etiese dimensies. Dit sal egter op die volgende wyses gevul word:

- Met 'n verpligte kursus (vanaf 2010) vir tweede- en derdejaar studente oor "Verstaan die wêreld"/“Understanding the world".

- Deur die reeds geformuleerde waardes van die NWU, wat op die hoofbeginsels van die nuwe Suid-Afrikaanse Grondwet (menswaardigheid, gelykheid en vryheid) gegrond is.

Wat die waardegedrewe (of etiese) institusionele kultuur betref, voel Eloff egter dat die elf waardes tot vier doenwaardes verminder kan word om die waardestelsel meer prakties te maak. Daar sou egter gevra kon word of waardes self nie reeds prakties van aard is nie. Volgens hom is die waardeprojek ook nie iets wat as afgehandel beskou kan word nie. Wat word daarmee bedoel?

Eloff is ten slotte van mening dat dit tans (2008) nie slegter gaan as destyds met die "CHO" nie. Die nuwe waardes moet slegs Christelik ingekleur word. Hierop sou gevra kon word of waardes dan min of meer neutrale dinge of vorme is, wat met bepaalde inhoude gevul kan word - 'n ou bekende dualisme? Is hulle nie alreeds deur 'n bepaalde religie/lewensvisie/ideologie ingekleur nie? 


\subsection{Kritiek op die NWU-waardes}

Teenoor dr. Eloff se aanpak vanuit 'n bestuursoogpunt, het prof. Venter die aangeleentheid vanuit die perspektief van 'n akademikus benader.

Hy noem eers die vier doenwaardes (van Maart 2007) en die personeel se verbasing, onbegrip, verergdheid en selfs verontwaardiging dat hulle (in Mei 2007) voorgeskrewe vorms moes voltooi om te bepaal tot watter mate aan dié waardes voldoen word. Volgens Venter het die ICARUS-projek om die volgende redes misluk: dit was nie lewensvatbaar nie, wou die akademici verander op grond van die veronderstelling dat hulle nie hulle rol na wense vervul nie, weens die vaagheid van die elf waardes, en as gevolg van die imperatiewe (top-down) hantering van die saak is die persepsie van 'n gedwonge projek geskep.

Verder stel Venter die vraag of die vier doenwaardes werklik waardes is. Volgens hom is waardes nie iets waarvan 'n mens oortuig moet word nie, maar iets waarin 'n mens self glo, diep van oortuig is en dus jou lewe daarvolgens inrig.

Verder is integriteit volgens Venter eerder 'n kwaliteit, toewyding 'n ingesteldheid, aanspreeklikheid is 'n verpligting en respek 'n gesindheid. Nie een van die vier doenwaardes kwalifiseer dus as 'n waarde nie. Verder sou hy graag wou weet wat die verskil tussen doen- en eindwaardes is.

Venter beveel dus aan dat die NWU liewer één kernwaarde, naamlik respek vir menswaardigheid - iets wat heelwaarskynlik vir alle lewensbeskouings aanvaarbaar sal wees - as kernwaarde aanvaar.

Ten slotte stel Venter teenoor Eloff se konklusie dat dit tans nie slegter as onder die ou CHO-bedeling sou gaan nie, dat die Puk sedert sy ontstaan alreeds 'n (Christelike) waardegedrewe universiteit was en dalk beter daarin geslaag het as die huidige waardegedrewe NWU. Die destydse visie van die Puk as "'n Universiteit van hoë gehalte, op Christelike grondslag, ondernemingsingesteld en diensgerig aan die land en sy mense" bevat volgens Venter meer akademies gekwalifiseerde waardes.

\subsection{Praktiese probleme tydens die bespreking}

Die bespreking na afloop van die lesings was nie diepgaande nie, maar het meestal oor allerlei praktiese fasette gehandel. Enkele persone het wel daarop gewys dat waardes nie dinge is wat in die 
lug hang nie, maar met duidelike norme/beginsels verband hou, wat op hulle beurt op religieuse geloof gegrond is. Dit het byvoorbeeld gegaan oor die elf waardes - of hulle almal werklik as waardes kwalifiseer, hoe hulle geoperasionaliseer kan word, en of waardes nie vanself die resultaat is van dinge doen nie - en waarom daar dan nog van doenwaardes gepraat word.

Verder is gevra of die waardestelsel net vir ondersteuningspersoneel (die administratiewe sektor) bedoel is, en of dit ook die dosentekorps insluit. Die vraag is gestel omdat die meeste waardes nie spesifieke akademiese of universiteitswaardes is nie. lemand het in hierdie verband die vraag gestel of die waardes nie impliseer dat van die universiteit ' $n$ bedryf gemaak word nie. In die lig van Eloff se onderskeid tussen 'n etiese institusionele kultuur en 'n verpligte "Verstaan die wêreld"-kursus vir studente, is gevra of daar enige verband tussen die twee spore is, en indien wel, wat die verband sal wees. Sal die waardes ook in die kursusse geïntegreer word?

Toe die leerplanne vir hierdie kursusse teen die einde van 2009 beskikbaar geword het, kon die skrywer nie 'n duidelike verband daarin met die NWU-waardes vasstel nie. Verskillende werklikheidsbeskouings (in die eerste kursus) en hulle implikasies vir die wetenskap (in die tweede kursus) word daarin behandel. Dit geskied waarskynlik op 'n manier soos die ou godsdiensvergelykende metode - ook genoem die fenomenologiese metode. Dosente moet blykbaar neutraal staan teenoor die verskillende lewensvisies en teorieë. Die studente moet dus self kies watter een van die talle religieë en/of lewensvisies die beste is. Neem die Potchefstroomkampus, wat vroeër tereg teen 'n neutrale beoefening van die wetenskap was, nou aan dié selfbedrog deel?

\section{Indringender, meer teoreties-filosofiese vrae}

Daar mag egter nie met hierdie min of meer voor die hand liggende kritiek volstaan word nie. Die volgende ses, meer indringender, vrae behoort gestel te word.

\subsection{Moralisering?}

Waardes lei maklik tot moralisme. Moralisme beteken ' $n$ verenging of redusering van die hele lewe tot een van die baie fasette daarvan, naamlik die morele of etiese. Daardeur kry die etiese 'n byna sentrale, religieuse betekenis, sodat mense se diepste geloofsoortuigings uiteindelik ook met oppervlakkige etiese moets en moenies vervang word (vgl. Van der Walt, 2010:22-47). So 'n etiese sousie of 
versiersuiker bo-op 'n instelling kan dit van buite beter laat lyk, maar geen grondige verbetering waarborg nie (vgl. Van der Walt, 2000: 305-310).

Dat hierdie nie 'n denkbeeldige gevaar is nie, blyk uit die lesings wat Landman (2009) op 22 Junie 2009 vir die topbestuurslede van die NWU aangebied het. Die outeur was self nie teenwoordig nie en weet dus nie wat die reaksies daarop was nie, maar het wel 'n kopie van die aanbieding ter insae gehad.

In die lig van die voorafgaande is 'n titel soos The practical application of values al te bevraagteken. Soos sal blyk (vgl. 5.6), is waardes volgens sekere reformatoriese denkers bloot die eienskappe van dinge (feite, gebeure of handelinge) wat ontstaan nadat die dinge (die draers van die waardes) positief aan dieperliggende norme beantwoord het. Waardes hoef dus nie - tensy hulle (subjektivisties) as norme beskou word - toegepas te word nie.

Die onderliggende (universele en konstante) vertrekpunte van menslike positiveringsarbeid word egter deur die moderne waardefilosofie misken en in werklikheid deur waardes vervang. Omdat waardes eintlik reeds positiverings is wat dan in die plek van die onderliggende universele en konstante vertrekpunte daarvan gestel word, beliggaam die ideaal van enige waardegedrewe gegewe op sigself reeds 'n subjektiveringselement. (Meer hieroor in 'n opvolgartikel.)

Die inhoud van Landman se lesing gaan ook uitsluitlik oor morele waardes - waardes word tot etiese waardes vereng. Dit gaan byvoorbeeld oor etiese waardes, etiese dilemmas, etiese keuses, organisasie, leierskap, ensovoorts. Ook die ou valse dilemma van feite en waardes steek kop uit. Die goue reël, "wat jy nie aan jouself gedoen wil hê nie, moet jy ook nie ander aandoen nie", of die positiewe formulering daarvan, kom wel na vore, maar speel as gevolg van die moralistiese opset van die geheel geen rigtinggewende rol daarin nie. Ook die bronne of gronde van waardes bly vaag. Uiteindelik blyk dit dat dit gemeenskappe is wat waardes of 'n sekere etiese kultuur skep en onderhou. So 'n standpunt is egter niks minder subjektivisties as wanneer die outonome individu of 'n konstitusie die bron van die waardes sou wees nie. Morele ontwikkeling word ook sonder enige transendente begronding verklaar.

Hierna stel Landman enkele vrae oor die NWU se elf waardes. Eers aan die einde, nadat die hele aangeleentheid grondig vermoraliseer is, word die vraag gestel, naamlik wat presies 'n universiteit is. Dit 
word egter nie deur die spreker beantwoord nie. Die hele voordrag is sover nagegaan kon word, ' $n$ pragtige voorbeeld van die vermoralisering van iets ('n universiteit), wat wel 'n etiese faset het, maar totaal andersoortig (nl. akademies) gekwalifiseerd is.

\subsection{Feit en waarde?}

' $n$ Volgende vraag ten opsigte van die NWU is hoe sy waardestelsel die verhouding tussen (etiese) waardes en (wetenskaplike) feite beskou. Word hierdie steeds gangbare, valse dualisme eenvoudig aanvaar? Blyk dit nie dalk reeds uit die tweesporige aanpak van sowel ' $n$ waardestelsel as ' $n$ inleiding (soos in die twee nuwe kursusse vir studente) hoe die wêreld (feitelik) verstaan behoort te word nie?

Olthuis (1968:186) verwerp uitdruklik so 'n soort dualisme:

There is no such a thing as a 'brute fact'. It is not that facts stand by themselves ... Facts can only be known in their meaning-character in relation to a law-order, and can only exist as law-confirmation. A certain fact is a fact when and because it answers to a certain law-structure (holding for facts of a typical kind) ... Without a law-order there could be no facts. Without the facts, as those which answer to and subjectively realize the demands of the law, the law-order would be meaningless.

Eenvoudige voorbeelde is die volgende: indien 'n groepie mense 'n gesin genoem word, word die norm vir 'n gesinslewe veronderstel. Wanneer van egbreuk gepraat word, is dit nie 'n naakte feit nie, maar word die huwelik as 'n normatiewe instelling veronderstel.

\subsection{Verkommersialisering?}

Dit is tans ' $n$ bekende feit dat verskillende samelewingsverbande wat nie 'n ekonomiese karakter dra nie - geleidelik verkommersialiseer word. Kompetisie, uitnemendheid, ondernemingsgerigtheid, bestuur en winsgewendheid word die belangrikste waardes, terwyl die unieke karakter van die huwelik, gesin, skool, universiteit, en so meer vermoor word. Ter versagting (of eerder kamoeflering) word egter 'n paar waardes by die keiharde pragmatistiese neo-kapitalisme bygevoeg. Tereg het iemand (vgl. 4.5) die vraag gestel of die nuwe waardes nie ook 'n simptoom hiervan by die NWU is nie. Die tyd alleen sal hieroor duidelikheid kan bring. 


\subsection{Verjuridisering?}

Insgelyks kan 'n volgende vraag oor die skeeftrek van die karakter van 'n universiteit (as unieke samelewingsverband met 'n eie taak en doel) gestel word, naamlik of die begronding van die NWU se waardestelsel (vgl. die eerste drie waardes hierbo) op die SuidAfrikaanse Grondwet en Handves van Menseregte (iets van politiesjuridiese aard) nie tot 'n verjuridisering en verpolitisering van 'n akademiese instelling lei nie? Alle menslike samelewingsverbande het wel ' $n$ juridiese faset, maar hulle is beslis nie juridiese instellings, of juridies gekwalifiseerd nie.

\subsection{Sekularisering?}

Miskien is hierdie punt nie meer ad rem nie - die Puk het moontlik alreeds voor 2004 besluit om 'n sekulêre instelling te word. Maar selfs indien dit nie die geval is nie, sal elf waardes - ook al word hulle met 'n Christelike inhoud gevul - nie die sekularisering van die NWU (die Potchefstroomkampus ingesluit) kan stuit nie. Die Christelike identiteit van 'n organisasie of instelling lê gelukkig veel dieper as 'n paar bolangse waardes wat bowendien nie eers vir die kernbesigheid van 'n universiteit (akademies gekwalifiseerd) relevant is nie.

Fowler (2009:51) bespreek teen die agtergrond van die hedendaagse (valse) dualisme tussen 'n (godsdienstige) private terrein en 'n (neutrale) publieke terrein verskillende modelle van Christelike onderwys waaronder ook die value-added model en sê daarvan die volgende (vgl. Boer, 2006 vir 'n verdere verduideliking van die gevaar van sekularisme vir Christene):

In this model the cultural norms of prevailing educational practice is modified by the addition of a set of moral values relating to individual conduct within a relatively narrow field ... There is no doubt that Christian teachers should teach and model sound moral values. However, this does not alter the secularist nature of the educational practice. It fits the secularist worldview perfectly ... The main body of learning remains shaped by a secularist worldview.

\subsection{Substansialisering?}

Die heel belangrikste vraag is egter nog nie geopper nie, naamlik wat presies die status en gesag van waardes is. Eers as hierdie vraag (wat waardes is) beantwoord is, kan ook die vraag beantwoord word of die NWU se waardes werklik nuwe rigting kan 
aandui nadat die ou (Christelike) koers van die $\mathrm{PU}$ vir $\mathrm{CHO}$ afgeskryf is.

Hoewel in 'n volgende bydrae in hierdie tydskrif breedvoerig op hierdie teoreties-filosofiese probleem ingegaan sal word, word by monde van net een reformatoriese denker nou reeds 'n voorlopige antwoord daarop gegee. Olthuis (1968:187) skryf soos volg:

Values in our view must simply be facts, acts, things, events which in a high degree live up to the relevant norms. These values in no way exist by themselves. Values are referential in character and only in this reference to the law-order they possess meaning ... In order to guard against the danger of substantialized values, it is the better part of caution to speak of having value: certain subjective conditions answer to the norm $\ldots$ it is not valuable simply because of a subjective arbitrary human choice ...

Waardes moet dus duidelik van goddelike wette en norme (beginsels) in die menslike lewe onderskei word. Hulle ontstaan eers as eienskappe nadat aan belangriker kriteria beantwoord is. Die hedendaagse subjektivisme verklaar egter waarom aan waardes normatiewe, rigtinggewende gesag toegeken word. Daar word nie meer duidelik onderskei tussen 'n godgegewe normatiwiteit en die subjekte (dinge) wat aan die normatiewe gehoorsaam moet wees nie. Eenvoudig gestel: wat is word tot die status van behoort verhef.

Dat so 'n standpunt uiters gevaarlik is, hoef nie verder verduidelik te word nie. Dit impliseer eenvoudig die aanvaarding van die politiekekonomies-sosiale status quo as normatief. Vir die NWU kan dit beteken dat dit koersloos kan meedobber op wat ook al die modewaardes van die tyd mag wees. In die finale instansie sal dit 'n soort identiteitslose instelling impliseer. Daarteenoor toon Van der Walt (2007:180 e.v.) juis aan hoe belangrik dit tans vir onderwysinstellings geword het om hulle institusionele identiteit te formaliseer - gesien in die lig van die geweldige rol wat 'n alles-gelykmakende globaliseringsproses speel.

\section{6. 'n Moontlike reformatoriese alternatief}

Die voorafgaande kritiek op 'n waardegedrewe universiteit maak dit noodsaaklik om - al is dit baie kortliks - 'n alternatief daarop te gee.

Die outeur het die vermoede dat die ANC-teenstanders van die Puk se Christelike karakter (behalwe natuurlik a.g.v. die Puk se apartheidsverlede) van mening was dat 'n Christelike universiteit die- 
selfde as 'n kerklike universiteit beteken het. Die Puk-bestuur het op hulle beurt blykbaar nie oor die nodige reformatoriese wapenrusting beskik om die bestaansreg van 'n Christelike universiteit te kon verdedig nie, afgesien daarvan dat hulle hulle nie op die Puk se grondwetlike regte beroep het nie (vgl. 2.4). Nie een van die twee partye het oor 'n geskikte samelewingsfilosofie beskik nie. Daarom word dit hier kortliks weergegee.

\subsection{Drie belangrike vrae}

Elke lewensvisie (vgl. Mouw \& Griffioen, 1993:17) moet antwoorde op drie basiese lewensvrae bied, naamlik wat alles bestaan (die strukturele vraag), hoe dit behoort te wees (die direksionele vraag), en wanneer geskied dit op 'n kultureel relevante wyse (die kontekstuele vraag). Elke mens moet byvoorbeeld vra: Wie is ek? Hoe behoort ek te lewe? en, Op watter wyse kan dit binne my eie kultuur gebeur?

Toegepas op 'n instelling vir hoër onderwys ontstaan die volgende vrae:

- Wat is 'n universiteit/kollege presies? Hierdie vraag vereis 'n struktuuranalise wat aantoon dat dit 'n eiesoortige samelewingsverband met 'n unieke taak is.

- Wat behoort die religieuse rigting daarvan te wees? Dit hang af van die religieuse of lewensbeskoulike instelling van die mense wat dit tot stand bring, ondersteun en daarin onderwys wil ontvang.

- Hoe kan dit werklik binne 'n spesifieke kulturele konteks relevant wees? Hoewel moderne universiteite sterk Westers georiënteerd is, behoort hulle in byvoorbeeld Afrika, Asië en Latyns-Amerika rekening te hou met die betrokke omgewing wat hulle wil dien, om relevante hoër onderwys te kan aanbied.

Hierdie drie fasette van 'n universiteit word hieronder (by 6.3) breër uitgewerk. Eers moet op die implikasies daarvan vir 'n breër samelewingsfilosofie gewys word.

\section{2 'n Pluralistiese samelewingsfilosofie}

Teenoor ' $n$ individualistiese en sosialistiese samelewingsbeskouing huldig reformatoriese denkers 'n pluralistiese visie. Volgens hierdie visie op die samelewing word twee soorte prinsipiële pluralismes onderskei, naamlik strukturele en konfessionele (religieuse en lewensbeskoulike) verskeidenheid. 


\subsubsection{Strukturele pluralisme}

Strukturele pluralisme beteken dat die samelewing uit 'n verskeidenheid menslike verbande, instellings en organisasies bestaan wat elkeen 'n eie verantwoordelikheid en eie gesagstruktuur besit. So 'n visie verwerp dus die individualistiese sowel as die kollektivistiese samelewingsbeskouings. Hiervolgens behoort 'n universiteit byvoorbeeld vry te wees van oorheersing deur die kerk, staat of sakewêreld. Dit impliseer egter nie dat daar wel noue bande tussen die verskillende menslike samelewingsverbande behoort te bestaan nie.

Strukturele verskeidenheid toegepas op Christelike onderwys beteken nie kerklike onderwys nie. 'n Kerkskool, kerklike kollege of universiteit mag goeie kerklidmate oplewer, sonder dat dit werklike Christelike skool- of tersiêre onderwys bied. Die rede hiervoor is dat 'n kerklike inrigting dikwels beskou word as 'n instrument vir die kerk om mense te bekeer, in plaas daarvan dat dit as 'n opvoedkundige instelling in eie reg beskou word.

\subsubsection{Konfessionele pluralisme}

Konfessionele pluralisme voeg hierby nog dat die selfstandigheid van verskillende menslike samelewingsverbande om hulle eie sake volgens hulle eie aard te reël, nie slegs erken moet word nie, maar hulle moet dit ook volgens hulle eie religieuse en lewensbeskoulike oortuigings kan doen. Met hierdie samelewingsbeginsel word die hedendaagse skeiding tussen private sake (waar geloof en lewensvisie wel 'n rol mag speel) en 'n publieke/openbare terrein (waaruit enige godsdienstige oortuigings verban is) verwerp. Dit is skyn dat die sogenaamde openbare terrein neutraal sou wees. Dit word vandag meestal deur 'n sekulêre geloof wat God en sy verordeninge nie wil erken nie, beheers. Hierdie sekulêre geloof het dus nie plek vir die Joodse, Islamitiese of Christelike godsdienste nie. Selfs 'n samelewingsfilosofie wat op algemene menseregte gegrond is, kan nie werklik reg laat geskied aan konfessionele verskeidenheid nie.

\subsubsection{Relevansie}

Die feit dat mense tans al meer in multireligieuse samelewings lewe, maak hierdie beginsel nóg meer aktueel. Spykman (1989:98) skryf:

We live in a religiously splintered world, surrounded by a wide range of contrasting faith communities. Pluralism, as an alternative way of living together in society, seeks to reckon seriously with these very real differences. It seeks to insure that the public as well as private rights in society be safeguarded ... 
it is neither sectarian nor parochial ... the rights that it affirms for one group in society it also advocates for others.

Die aktualiteit van konfessionele pluralisme blyk byvoorbeeld daaruit dat Boer $(2006: 16,17)$ dit as die enigste werklike oplossing beskou vir die jarelange bloedige stryd in Nigerië tussen 60 miljoen Christene en 60 miljoen Moslems om seggenskap op die openbare terrein. Die oplossing is dus nie om religieuse en lewensbeskoulike verskille te ontken, in 'n private hoekie weg te steek, of in 'n eenheid van etniese, kerklike, politieke of ekonomiese aard te dwing nie, want hulle bestaan werklik en kom op elke lewensterrein na vore.

So 'n samelewingsvisie impliseer nie godsdienstige relativisme, naamlik dat alle godsdienste prinsipieel ewe waar/vals is nie. Dit beteken wel dat 'n mens verdraagsaam sal moet wees teenoor standpunte en handelinge waarmee jy volgens eie geloofsoortuigings nie kan instem nie.

\subsubsection{Toegepas op die akademie}

Spykman (1985:54) verduidelik die belang van die onderskeid tussen struktuur en rigting vir die ter sake onderwerp soos volg:

The idea of structural pluralism refers to honoring the institutional identity of the Christian academy as it interacts in a co-existing and pre-existing way with the church, the state, its supporting community of homes and other contextual agencies ... The idea of confessional identity refers to maintaining the religious/philosophical integrity of a Reformed Christian academy (or any other) in the exercise of its educational office. How can a Christian academy, so conceived, make its unique scholarly contributions to the covenant life and kingdom programmes of the Reformed community? And how can it benefit the society and the nation and the world within which it is called to be a blessing?

Daarom voeg Spykman (1985:58) daarby:

... a Christian academy is to be governed by trustees representing the Reformed community, not by the church or the state. While such a university is related confessionally to the church and juridically to the state, it must cherish and exercise faithfully its own God-given sovereignty to carry on Christian scholarship in obedience to the Word of God. 


\subsection{5 'n Skending van akademiese vryheid}

Uit die voorafgaande is dit duidelik dat dit tot die kollektiewe vryheid van 'n universiteit as instelling behoort om sy eie rigting (religieuse oriëntasie) te bepaal, byvoorbeeld Christelik, Moslem of sekulêr. Die owerheid besit nie die bevoegdheid om hierdie rigting voor te skryf nie. Hoogstens kan die standaard van universiteite wat staatsubsidie ontvang, getoets word. Ewe min kan die staat aan individuele wetenskaplikes voorskryf watter standpunt (rigtingkeuse) hulle in hulle wetenskapsbeoefening moet inneem. Christelike wetenskapsbeoefening behoort daarom nóg op persoonlike vlak, nóg op gesamentlike vlak gekortwiek te word.

Die owerheid het dus die Puk se akademiese vryheid geskend deur te verwag dat dit 'n neutrale instelling word. Daarmee word natuurlik geen neutraliteit bereik nie, maar word die sekularisme as lewensvisie gevestig. Die Puk-bestuur het ook nie genoeg op hulle regte gestaan om sy Christelike karakter te behou nie. Hierdie regte is reeds onder 2.4 verduidelik.

Vervolgens moet nog iets meer gesê word oor hoe struktuur, rigting en kultuur saamgaan in ' $n$ werklik relevante Christelike universiteit/ kollege.

\section{3 'n Relevante Christelike akademie}

Behalwe dat 'n Christelike universiteit 'n vrye instelling is - vry van oorheersing van ander samelewingsektore - moet dit ook aan die volgende vereistes voldoen: dit moet 'n akademiese instelling wees, Christelik wees, of van 'n ander religieuse oriëntasie getuig, en dit moet relevant vir sy spesifieke konteks wees (vgl. Sewell, 1995).

\subsubsection{Strukturele analise}

'n Politieke instelling (die staat) is juridies gekwalifiseer en 'n kerk (tempel, sinagoge, moskee) is ' $n$ instelling om die geloof te versterk. 'n Universiteit het wel verbande met die staat en kerk, ekonomie, gesinslewe, en so meer, maar verskil van hulle almal, omdat dit 'n akademiese instelling is. Kerke en regerings kan dus as 'n noodmaatreël instellings vir hoër onderwys tot stand bring en ondersteun, maar behoort steeds in gedagte te hou dat dit 'n eiesoortige karakter het. Hulle mag dus nie verpolitiseer, verkerklik of verkommersialiseer word nie.

Akademici soek die verbande (ooreenkomste en verskille) tussen verskynsels in die werklikheid en die wetmatighede wat al dié dinge 
beheers. Omdat God se skepping so ryk is, is spesialisasie nodig. Nogtans behoort elke vakwetenskaplike ook met 'n breë kyk (werklikheidsvisie) toegerus te wees. Die akademiese taak van 'n universiteit is om jong, onervare studente as vakleeringe aan die wetenskaplike proses te laat deelneem, sodat ook hulle sowel grondliggende perspektiewe as gespesialiseerde kennis (nodig vir 'n bepaalde beroep) kan opdoen (vgl. Venter, 1994:298). Hierdie hoë roeping mag nie ondergeskik gemaak word - soos dikwels vandag gebeur - aan ekonomiese belange nie. 'n Ware universiteit is nie ' $n$ bedryf wat sy kliënte (die studente) so gou as moontlik van 'n graad voorsien om geld in 'n professionele beroep te kan maak nie. Ook 'n Christelike universiteit behoort in die eerste plek aan hierdie norme vir universiteitwees te beantwoord.

Op die vraag na 'n (Christelike) universiteit se bestaansreg, antwoord Seerveld (2000:4) soos volg:

A university is an institutional community of an older and younger generation of scholars and students whose calling together is to discover and cultivate God's world with informed, imaginative reflection, and then as responsible, responding human subjects coram Deo together articulate their required wisdom in awed thanks to God, sharing its blessings with one's neighbours, and by taking care of all God's marvellous creatures, including animals, plants and stones.

Elders stel hy dit so:

The reason a university should exist is to glean God's wisdom from creation and history, and to pass on the Lord's wisdom from one generation to another ... A university is called to lead God's people and our neighbours in good patterns of thinking, speaking, imagining, living. (Seerveld, 2000:9.)

\subsubsection{Die rigting}

Hoewel struktuur van rigting onderskei moet word, impliseer dit nie 'n skeiding nie, omdat die rigting nie 'n terloopse, addisionele toevoeging is nie, maar 'n wesenlike deel van 'n universiteit. By die behandeling van konfessionele pluralisme, is reeds genoem dat die rigting van 'n samelewingsverband op sy religieuse ingesteldheid en grondliggende lewensvisie dui.

- Die belangrikheid van die Christelike filosofie Hart (1969:61) skryf soos volg oor 'n Christelike universiteit: 


\begin{abstract}
A ... noteworthy characteristic will be its insistence that it has no justifiable reason for existing unless its biblical commitment comes to expression in whatever is the proper business of the university. If it exists merely to guard the faith and undergrid the morals of its students, it will as a Christian university be a failure. But when a [Calvinistic] cosmoscope [worldview] ... receives its theoretical counterpart in a Christian philosophy, which in turn fosters a biblical development in each academic field, then the name Christian university will begin to have true meaning.
\end{abstract}

Net soos Hart is ook Seerveld daarvan oortuig dat 'n Christelike universiteit sonder die grondslag van 'n Christelike filosofie (die wetenskaplike besinning oor 'n voorwetenskaplike Christelike lewensvisie) nie moontlik is nie.

By a Christian philosophical systematics I mean the practice of theory oriented toward probing the structural aspects of things, persons, acts and events, ferreting out the interrelated meaning of the matters under scrutiny ... philosophy is more a set of fundamental questions than a number of answers; philosophy is a constellation of categories within which one proceeds to think and make conceptual judgements. A Christian philosophical systematics itself will be a network of leading ideas that order how we analyse specific affairs and construe their encyclopedic connections, and this network of leading ideas will be marked by biblical wisdom. (Seerveld, 2000:5.)

In die geval van 'n Christelike instelling vir hoër onderwys sal die hoogste religieuse norm God se liefdeswet wees. Liefde is egter soos 'n reënboog, dit neem verskillende kleure aan en mag veral nie moralisties vereng word nie. Antonides (1985:199) waarsku dat die liefdesgebod nie op 'n ongedifferensieerde manier toegepas mag word nie. As voorbeeld noem hy die terrein van die staat en dat Christene soms geregtigheid (die taak van die staat) as minderwaardig teenoor die liefdeswet beskou, terwyl geregtigheid juis die vorm is wat die liefdesgebod op politieke terrein moet aanneem. Elders herhaal Antonides (1985:217) dit soos volg:

The love command, which is indeed central to human life, must be expressed in a variety of ways in a diversity of cultural situations. It is obvious, for example, that we cannot expect to solve political and economic problems by means of purely ethical solutisons.

Die liefdeswet moet dus, net soos in ander samelewingsverbande, 'n eiesoortige vorm aanneem, 'n konkrete, akademiese gestalte kry. 
Hoe sou 'n universiteit daarop gebou kon word? As bewys dat dit wel moontlik is, word slegs na een van baie moontlike skrywers verwys. Venter (1994:300 e.v.) stel nie net baie duidelik wat die unieke taak van 'n universiteit is nie, hy bied ook 'n helder uiteensetting van wat die norme vir so 'n akademiese instelling behoort te wees (vgl. Venter, 1994:327-332). Hierdie norme is nie net van toepassing op 'n Christelike instelling nie - dit kan ook vir die NWU geld. Sulke akademiese vertrekpunte kan verder - teenoor die neo-barbarisme van die hedendaagse wêreldkultuur - help om werklike beskawing aan universiteite te waarborg.

\section{- $\quad$ Spesifieke akademiese norme}

Spesifieke akademiese norme beteken onder andere kreatiewe, kritiese denke, goeie insig in probleme, logiese afleidings, duidelike formulerings, kontrole van die wetenskaplike resultate. Op al hierdie verskillende wyses word die liefde tot jou spesifieke vak en teenoor jou studente en kollegas konkreet gemaak. Nog eenvoudiger gestel: op 'n Christelike akademiese instelling leer 'n mens om God diep uit jou hart en ook met jou verstand lief te hê (vgl. Matt. 22:37).

Om dit alles moontlik te maak, formuleer die meeste instellings vir Christelike hoër onderwys gewoonlik 'n eie grondslag, doelstelling of waardes (vgl. Swanepoel \& Van der Walt, 1985). Sulke regulerende en rigtinggewende norme word deur 'n universiteitsgemeenskap beskou as relevant vir hulle gemeenskaplike taak en as die basis waarop hulle saamwerk.

Omdat 'n universiteit iets anders as 'n kerk is, kan hierdie grondslag nie kerklike belydenisskrifte (soos die Heidelbergse Kategismus, Dordtse Leerreëls of Nederlandse Geloofsbelydenis in die geval van die gereformeerde kerke) wees nie. Sulke konfessionele verskille is wel vir die kerk belangrik, maar behoort in die geval van Christelike kolleges en universiteite nie onoorbrugbaar te wees nie, sodat dit moontlik is om oor denominasionele grense as Christene saam te werk (vgl. Venter, 1994:316).

\subsubsection{Relevansie}

In die derde plek moet nie net seker gemaak word dat instellings vir hoër onderwys werklik universiteite en daarby Christelike (of religieus anders georiënteerde) universiteite is nie, maar ook dat hulle relevante instellings vir hulle kulturele omgewing is. Behalwe strukturele en konfessionele pluralisme moet kulturele pluralisme ook erken en toegepas word. 
Hoewel die oudste universiteite op Afrikabodem ontstaan het, is hedendaagse universiteite as gevolg van globalisering meestal kulturele produkte van die Weste. Vir baie Afrikane (en seker ook vir mense uit Asië en Latyns-Amerika) kan universitêre studie dus 'n groot kultuurskok inhou.

Die westerse kultuur en universiteitswese is egter allermins volmaak en nog minder die maatstaf vir die hele wêreld se universiteite. Daar lê dus 'n groot uitdaging voor vir volke in die suidelike halfrond om kultuurvriendelike en kultuurrelevante instellings tot stand te bring wat na werklike oplossings vir hulle eie unieke probleme sal soek. (Vgl. Van der Walt, 1998:385-396 oor enkele kenmerke wat 'n inheemse Afrika-universiteit sou weerspieël.)

\section{Nabetragting en 'n voorlopige gevolgtrekking}

$\mathrm{Na}$ aanleiding van die voorafgaande sou die volgende drie vrae ten slotte gestel kon word:

\subsection{Ná die maal?}

Lesers mag van mening wees dat hierdie postmortemondersoek erg na die suur druiwe van 'n beterweterige oud-Puk smaak. Waarom so 'n lang betoog, terwyl dit 'n feit is dat die NWU nou 'n waardegedrewe universiteit geword het? Die outeur dink tog nie dat hy met hierdie artikel die koers van die skip sal kan verander nie! Of sou dit dalk tog moontlik wees?

'n Antwoord hierop sou die volgende kon wees: Eerstens is hierdie bydrae nie uit beterweterigheid geskryf nie, maar dit het ontstaan uit hartseer oor die pad wat 'n belangrike Christelike instelling geloop het. Tweedens is dit geskryf met die oog op die toekoms. Ook al word gesê dat al wat mense uit die geskiedenis leer, is dat hulle niks daaruit leer nie, bly die geskiedenis 'n belangrike leerskool. Waardegedrewenheid is tans so populêr dat wat hier gegee is (vgl. veral punt 6) in die toekoms moontlik tog vir die Potchefstroomkampus (vgl. opvolgartikel) van waarde kan wees en selfs ander Christelike organisasies en instellings kan waarsku oor hoe hulle met hierdie modegier moet omgaan.

\subsection{Net negatief?}

Die gevolgtrekking uit die voorafgaande is duidelik dat 'n mens versigtig met waardes moet omgaan. Reformatoriese denkers (soos Olthuis) is nie sonder rede skepties daaroor nie. Ook Wolters 
(1992:15) skryf dat die gesekulariseerde westerse mens wel nog in vaste natuurwette glo, maar lankal vaste norme vir menslike gedrag laat vaar het. "Hulle sal hoogstens van 'waardes' praat, 'n term wat boekdele spreek oor die poging van die teenswoordige mensdom om hom van alle goddelike bevele te bevry."

\section{3 'n Finale oordeel?}

'n Leemte in hierdie besinning oor waardes is dat, alhoewel gesuggereer is wat waardes behels, hierdie filosofiese vraag nie grondig genoeg aandag ontvang het nie. Daarom word ten slotte slegs van 'n voorlopige gevolgtrekking melding gemaak. Die hele artikel roep om voortsetting, om 'n konseptuele raamwerk, om 'n filosofiese besinning oor waardes.

\section{Geraadpleegde bronne}

ANON. 1991. De vrije Universiteit: gewoon bijzonder. Amsterdam: Vrije Universiteit.

ANTONIDES, H. 1985. Stones for bread: the social gospel and its contemporary legacy. Jordan Station: Paideia.

ASPIN, D.N. \& CHAPMAN, J.D., eds. 2007. Values, education and lifelong learning: principles, policies and programmes. Dordrecht: Springer.

BOER, J.H. 2006. Christians: secularism - yes and no. Belleville: Essence.

BRINKMAN, H.J. 1992. Identiteit van de Vrije Universiteit. Amsterdam: Vrije Universiteit.

DE KLERK, J. \& RENS, J. 2003. The role of values in school discipline. Koers, 68(4):353-371.

DORDT COLLEGE. 1961. Statement of purpose: seventeen propositions. Sioux Center: Dordt College Press.

DORDT COLLEGE. 1968. Scripturally-oriented higher education. Sioux Center: Dordt College Press.

DORDT COLLEGE. 1979. The educational task of Dordt College. Sioux Center: Dordt College Press.

DORDT COLLEGE. 1993. The educational framework of Dordt College. Sioux Center: Dordt College Press.

DORDT COLLEGE. 1996. The educational task of Dordt College. Sioux Center: Dordt College Press.

DUVENAGE, B., red. 1971. Besinning en uitsig. Potchefstroom: PU vir CHO.

DUVENAGE, S.C.W., red. 1969. Die atoomeeu - "in U lig". Potchefstroom: Instituut vir die Bevordering van Calvinisme.

ELOFF, T. 2008. Waarom is die Noordwes-Universiteit ' $n$ waardegedrewe Universiteit en wat word daarmee bedoel? Lesing gelewer by die PukForum op die Potchefstroomkampus van die Noordwes-Universiteit op 4 Sept. 2008.

FOWLER, S. 2009. Living worldviews. Melbourne: Amani Educational Services. HAAN, B.J. 1992. A zeal for Christian education: the memoirs of B.J. Haan. Sioux Center: Dordt College Press. 
HAAN, W. \& VAN HARSKAMP, A., reds. 1991. Vrij van kerk, staat ... en verleden? Moet het bijzondere van de VU worden afgeschaft? Amsterdam: Vrije Universiteit.

HAAN, W. \& VAN HARSKAMP, A., reds. 1993. De identiteit van de Vrije Universiteit: discussie over en commentaar bij de rede van drs. H.J. Brinkman. Amsterdam: Vrije Universiteit.

HART, H. 1969. Calvinism as a cosmoscope. (In Duvenage, S.C.W., red. Die atoomeeu - "in U lig". Potchefstroom: Instituut vir die Bevordering van Calvinisme. p. 52-61.)

HULST, J.B. 2005. A doorkeeper in God's household: the memoirs of John B. Hulst. Sioux Center: Dordt College Press.

LANDMAN, W.A. 2009. The practical application of values. Fotokopie van 'n powerpoint-lesing gelewer op 22 Jun. 2009 by die Noordwes-Universiteit. (Ongepubliseer.)

MOUW, R.J. \& GRIFFIOEN, S. 1993. Pluralisms and horizons: an essay in Christian public philosophy. Grand Rapids: Eerdmans.

NOORDWES-UNIVERSITEIT. 2007. ICARUS: doenwaardes om spangees en vertroue uit te bou. Eish, 1(2):12, Sept.

NOORDWES-UNIVERSITEIT. 2009. Nuwe waardes vir die NoordwesUniversiteit. NWU in fokus, 1(1):1.

NWU

kyk NOORDWES-UNIVERSITEIT

OLTHUIS, J.H. 1968. Facts, values and ethics. Assen: Van Gorcum.

REINECKE, C.J., red. 1998. Verkennings en oorgang: gedagtes by die 125jarige bestaansjaar van die PU vir $\mathrm{CHO}$ - 1994. Koers, Supplement 1:1433.

ROELINK, J. 1979. Een blinkend spoor: beeld van een eeuw geschiedenis der Vereniging voor Wetenschappelijk Onderwijs op Gereformeerde Grondslag. Kampen: Kok.

SCHUTTE, G. 2005. De Vrije Universiteit en Zuid-Afrika (2 dele). Zoetermeer: Meinema.

SEERVELD, C. 2000. Why should a university exist? Insert to Contact (newsletter of the International Association for the Promotion of Christian Higher Education): 1-10, Nov.

SEWELL, K.C. 1995. The idea of a free Christian university. Potchefstroom: Institute for Reformational Studies. (Study pamphlet, 334.)

SPYKMAN, G.J. 1985. Christian higher education in global perspective: a call to ongoing reformation. Orientation: international circular of the PU for $C H E$, 37:46-58.

SPYKMAN, G.J. 1989. The principled pluralist position. (In Smith, G.S., ed. God and politics: four views on the reformation of civil government. Philipsburg: Presbyterian \& Reformed Publication. p. 78-99.)

STRAUSS, D.F.M. 2009. Philosophy: discipline of the disciplines. Grand Rapids: Paedeia.

SWANEPOEL, R. \& VAN DER WALT, B.J. 1985. Credo's of institutions for Christian higher education. Orientation: international circular of the $P U$ for CHE, 37:1-39, Jun.

SWARTZ, S. 2006. A long walk to citizenship: morality, justice and faith in the aftermath of apartheid. Journal for moral education, 35(4):551-570.

TERVOORT, A. 2005. 125 jaar Vrije Universiteit: wetenschap en samenleving. Amsterdam: Free University. 
TIMMERMAN, J.J. 1975. Promises to keep: a centennial history of Calvin College. Grand Rapids: Eerdmans.

VAN DER VYVER, J.D. 1999. Institutional perspective or church-state relations in South Africa. Brigham young university law review, 2:635-672.

VAN DER VYVER, J.D. 2000. Die uitdagings van die nuwe eeu vir die Puk as 'n Christelike universiteit op Suid-Afrikaanse bodem. Lesing gehou op 7 Jul. 2000 by die Puk-Forum van die PU vir CHO. (Ongepubliseer.)

VAN DER WALT, B.J. 1992. 'n Credo vir Christenwetenskaplikes. (In Van der Walt, B.J. Venster op die werklikheid. Potchefstroom: PU vir CHO. p. 541545.) (Reeks DSP, nr. 13.)

VAN DER WALT, B.J. 1994. A credo for an institution for Christian higher education. (In Van der Walt, B.J. The liberating message: a Christian worldview for Africa. Potchefstroom: The Institute for Contemporary Christianity in Africa. p. 592-596.)

VAN DER WALT, B.J. 1998. Flitsgedagtes oor die identiteit van die PU vir CHO (1869-1994). Koers, Supplement 1:363-400.

VAN DER WALT, B.J. 2000. Meer etiek is nie die oplossing vir die huidige krisis van normloosheid nie. (In Van der Walt, B.J. Visie op die werklikheid: die bevrydende krag van 'n Christelike lewensbeskouing en filosofie. Potchefstroom: PU vir CHO. p. 284-285, 296-304, 305-310.)

VAN DER WALT, B.J. 2010. The directives of God's Word for ethical/moral behaviour. (In Van der Walt, B.J. At home in God's world. Potchefstroom: The Institute for Contemporary Christianity in Africa. p. 22-47.)

VAN DER WALT, J.L. 2007. Formalizing institutional identity. (In Aspin, D.N. \& Chapman, J.D., eds. Values education and lifelong learning. Dordrecht: Springer. p. 180-198.)

VAN DEURSEN, A.T. 2008. The distinctive character of the Free University in Amsterdam. Grand Rapids: Eerdmans.

VAN EEDEN, E.S., red. 2006. "In U lig": die PU vir $\mathrm{CHO}$ van selfstandigwording tot samesmelting, 1951-2004. Potchefstroom: Noordwes-Universiteit.

VAN RIESSEN, H. 1982. Wetenschap in het licht van de verhouding van denken en geloven. (In Brüggemann-Kruijff, A. Th., Groenewoud, G., Huussen, G.M. \& Santema, J.H., reds. Geloven en denken. Amsterdam: VU Boekhandel. p. 119-192.)

VANDEN BOSCH, M. 1990. The history of Dordt College: the B.J. Haan years. Sioux Center: Dordt College Press.

VANDER VENNEN, R.E. 2008. A university for the people: a history of the Institute for Christian Studies. Sioux Center: Dordt College Press.

VENTER, F. 2008. Die Noordwes-Universiteit se waardeprojek krities beoordeel. Lesing gelewer by die Puk-Forum op die Potchefstroomkampus van die Noordwes-Universiteit op 4 Sept. 2008. (Ongepubliseer.)

VENTER, J.J. 1994. Reformational university: basis and operation. Orientation: international circular of the PU for CHE, (71-74): 295-336.

VERHOOGT, J.P. 1981. De doelstelling van de Vrije Universiteit: stromen van instemming. Amsterdam: Vrije Universiteit.

WOLTERS, A.M. 1992. Die skepping herwin: bybelse grondslae vir 'n reformatoriese lewensbeskouing. Potchefstroom: $\mathrm{PU}$ vir $\mathrm{CHO}$.

ZYLSTRA, C. 2004. The educational task of Dordt College \& the educational framework of Dordt College. (In Kok, J.H., ed. Celebrating the vision: the reformed perspective of Dordt College. Sioux Center: Dordt College Press. p. 1-16, 17-24.) 


\section{Kernbegrippe:}

Noordwes-Universiteit

Potchefstroomse Universiteit vir $\mathrm{CHO}$ universiteit, Christelike

waardes

Key concepts:

North-West University

Potchefstroom University for CHE university, Christian

values 
